\title{
MAGNETIC PROPERTIES AND ANTIBACTERIAL ACTIVITY OF TETRANUCLEAR COPPER COMPLEXES BRIDGED BY OXO GROUP.
}

\author{
P. CORTES ${ }^{1}$, A.M. ATRIA ${ }^{1 *}$, M. CONTRERAS ${ }^{l}$, M.T. GARLAND', O. PEÑA ${ }^{3}$, \\ G. CORSINI \\ ${ }^{1}$ Facultad de Ciencias Químicas y Farmacéuticas. Universidad de Chile. Santiago, Chile. \\ ${ }^{2}$ Facultad de Ciencia Físicas y Matemáticas and CIMAT. Universidad de Chile. Santiago, Chile. \\ ${ }^{3}$ L.C.S.I.M./UMR 6511 CNRS /Institut de Chimie de Rennes. Université de Rennes I, Rennes, Francia. \\ ${ }^{4}$ Laboratorio de Bacteriología Molecular. Facultad de Ciencias de la Salud. Universidad Diego Portales. Santiago, Chile.
}

\begin{abstract}
A series of three tetranuclear $\mathrm{Cu}(\mathrm{II})$ complexes of general formula $\left[\mathrm{Cu}_{4} \mathrm{OCl}_{6} \mathrm{~L}_{4}\right]$, where $\mathrm{L}$ is a Lewis Base ligand has been characterized through magnetic measurements and determination of antimicrobial activities.

This study include the following species $\left.\left[\mathrm{Cu}_{4} \mathrm{OCl}_{6}\right) \mathrm{Cl}(\mathrm{PhIm})_{3}\right](\mathrm{HPhIm}) \cdot \mathrm{H}_{2} \mathrm{O}(1)$ where $\mathrm{PhIm}=4$-phenylimidazole, $\left[\left(\mathrm{Cu}_{4} \mathrm{OCl}\right)_{6}\right)\left(\mathrm{PyNO}_{4}\right)^{1 / 1}{ }_{5}\left(\mathrm{H}_{2} \mathrm{O}\right)(2)$ where $\mathrm{PyNO}=$ Pyridine-N-oxide and $\left[\left(\mathrm{Cu}_{4} \mathrm{OCl}_{6}\right)(\mathrm{MeIm})_{4}\right] \cdot 3\left(\mathrm{CH}_{3} \mathrm{OH}\right)(3)$ where MeIm $=2$-methylimidazole.

The polynuclear cluster in the complexes contains a central oxygen atom tetrahedral coordinated to four copper(II) ions, each of which coordinates a monodentate L ligand. Each pair of copper atoms is bridged by on a chlorine ion, resulting a trigonal bipiramidal environment.

The variable temperature magnetic susceptibilities of these complexes were investigated in the temperature range 5-300K.

Satisfactory fits to the observed susceptibility data were obtained only for the complexes (1) and (3), by assuming isotropic magnetic exchange interactions and using the appropriate spin Hamiltonian and susceptibility equation giving the coupling constants $\mathrm{J}_{1}=0.148 \mathrm{~cm}^{-1}, \mathrm{~J}_{2}=-1.707 \mathrm{~cm}^{-1}$ for $(1)$ and $\mathrm{J}_{1}=0.522 \mathrm{~cm}^{-1}, \mathrm{~J}_{2}=-5.32$ $\mathrm{cm}^{-1}$ for (3).

The antimicrobial activities of these complexes have been screened in vitro against Gram positive and negative bacteria.
\end{abstract}

Keywords: Copper, magnetism, antibacterial activities.

\section{INTRODUCTION}

Copper (II) is probably the most extensive studied among the transition metal ions. This is due to their lability, their high affinity with different ligands and the wide variety of ligands geometries that can accommodate.

Due to their importance in biological processes and industrial application, copper(II) complexes synthesis and activity studies have been the focus from different perspectives.

Copper(II) complexes have found possible medical uses in the treatment of many diseases including cancer $[1,2]$. On the other hand, an increasing number on antibacterial activity studies in copper complexes have been reported [3,5].

Significant research from experimental and theoretical viewpoint have devoted to analyzing the polynuclear $\mathrm{Cu}$ (II) complexes with various bridges between the metal centers, matter in connection with their magnetic behaviour and design of new catalysts [6-8].

We report here the synthesis, magnetic properties and antibacterial activity of the $\left[\left(\mathrm{Cu}_{4} \mathrm{OCl}_{6}\right) \mathrm{Cl}(\mathrm{PhIm})_{3}\right] \cdot(\mathrm{HPhIm}) \cdot \mathrm{H}_{2} \mathrm{O}(1),\left[\left(\mathrm{Cu}_{4} \mathrm{OCl}_{6}\right)(\mathrm{PyNO})_{4}\right]^{\cdot 1}{ }_{5}\left(\mathrm{H}_{2} \mathrm{O}\right)$ (2) and $\left[\left(\mathrm{Cu}_{4} \mathrm{OCl}_{6}\right)(\mathrm{MeIm})_{4}\right] \cdot 3\left(\mathrm{CH}_{3} \mathrm{OH}\right)(3)$, complexes which contains both $\mu_{4}{ }^{-}$ bridging oxygen and $\mu$-halogens in their structures.

\section{Experimental section}

All chemicals and reagents are commercially available and were used as received without further purification.

\section{Synthesis}

The copper (II) complexes were synthesized by the method previously reported [9]. A methanol solution of the organic ligand (1 mmol) was added with constant stirring to a solution containing copper chloride $(1 \mathrm{mmol})$ in the same solvent. The resulting solution was refluxed for $45 \mathrm{~min}$. Single crystals suitable for X-ray analysis were obtained by slow evaporation of the solution of the complexes in methanol. 1108 .

C, $\mathrm{H}$ and $\mathrm{N}$ microanalyses were carried out with Fison Carlo Erba EA

Anal. Calcd for complex $\mathrm{Cu}_{4} \mathrm{O}_{2} \mathrm{C}_{36} \mathrm{H}_{31} \mathrm{~N}_{8} \mathrm{Cl}_{6}(1)$ : C, 38.95; $\mathrm{H}, 2.82 ; \mathrm{N}$, 10.09 Found C, 38.70; H, 2.78; N, 9.89.

Calcd. for complex $\mathrm{Cu}_{4} \mathrm{O}_{52} \mathrm{C}_{20} \mathrm{H}_{20.4} \mathrm{~N}_{4} \mathrm{Cl}_{6}(2) ; \mathrm{C}, 27.71 ; \mathrm{H}, 2.37 ; \mathrm{N}, 6.46$ Found C, 27.69; H, 2.11; N, 6.25.

Calcd. for complex $\mathrm{Cu}_{4} \mathrm{O}_{4} \mathrm{C}_{19} \mathrm{H}_{36} \mathrm{~N}_{8} \mathrm{Cl}_{6}(3) ; \mathrm{C}, 25.15 ; \mathrm{H}, 4.00 ; \mathrm{N}, 12.34$. Found C, 24.99; H, 3.87; N, 12.07 .

\section{Magnetic Measurement}

The magnetic susceptibility of (1), (2) and (3) complexes were determined over the temperature range $5-300 \mathrm{~K}$ by using a SQUID magnetometer (QUANTUM DESING MODEL MPMS-XL5 instrument) with a field of $0.1 \mathrm{~T}$. The data were corrected to compensate for the diamagnetism of the constituent atoms using the Pascal's constant, and also corrected for the temperature independent paramagnetism $60 \times 10^{-6} \mathrm{~cm}^{-3} \mathrm{~mol}^{-1}$ per copper (II).

\section{Antibacterial activity}

Bacterial strains used in this study are property of the Molecular Bacteriology Laboratory collection (Universidad Diego Portales). Staphylococcus aureus AB68 Streprococcus sp. SJD1025, Acinetobacter baumannii PL9060, Bacillus cereus GCA250, Citrobacter sp., Proteus vulgaris, Klebsiella pneumoniae RYC492 and Shigella flexnerii strains were isolated from clinical samples while the Escherichia coli BL21 strain was obtained from Novagen Inc. and Escherichia coli $\mathrm{DH} 5 \alpha$ strain was obtained from Gibco BRL.

Bacteria were grown in Mueller Hinton Agar (Difco) as Mueller Hinton broth (Difco) for 16 to $24 \mathrm{~h}$ at $37^{\circ} \mathrm{C}$ in an incubator.

The in vitro antibacterial activity of the complexes was tested using the paper disc diffusion method [10] and quantitative antibacterial activity was determined using minimum inhibitory concentration method (MIC) [11].

\section{RESULTS AND DISCUSSION}

In the complexes studied here, the copper (II) atoms are configured in a tetrahedron around the $\mu_{4}$-bridging central oxygen. Each one of the four copper atoms is bridged by $\mu_{2}$-halides. In the complexes the $\mathrm{Cu}_{4} \mathrm{OCl}_{6}$ nucleus is highly symmetric.

The major differences found in the complexes are due to the external ligands attached to copper: three PhIm ligands and one chloride ion in (1), four PyNO ligands in (2) and four MeIm ligands in (3). Figures 1 to 3 show individual ellipsoid plots of the three compounds. 


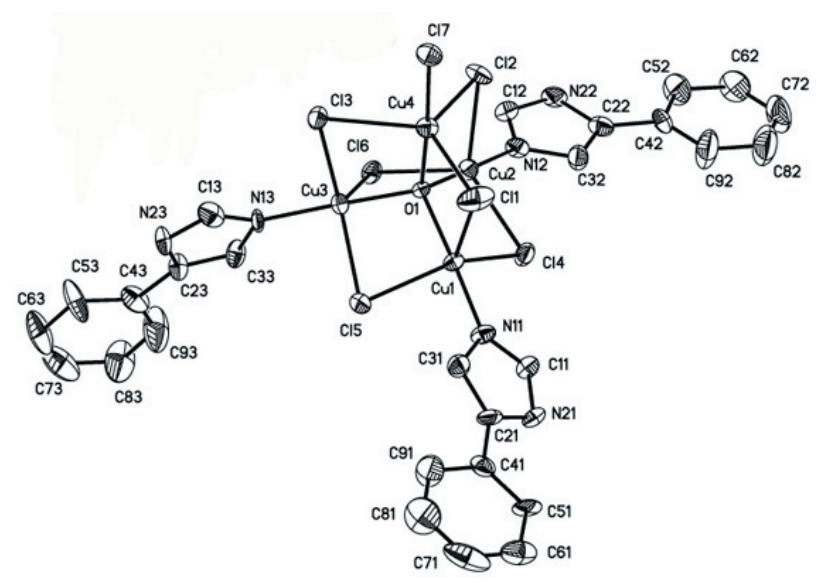

Fig. 1: Molecular Structure of $\left.\left[\mathrm{Cu}_{4} \mathrm{OCl}_{6}\right) \mathrm{Cl}(\mathrm{PhIm})_{3}\right](\mathrm{HPhIm}) \cdot \mathrm{H}_{2} \mathrm{O}$ (1).

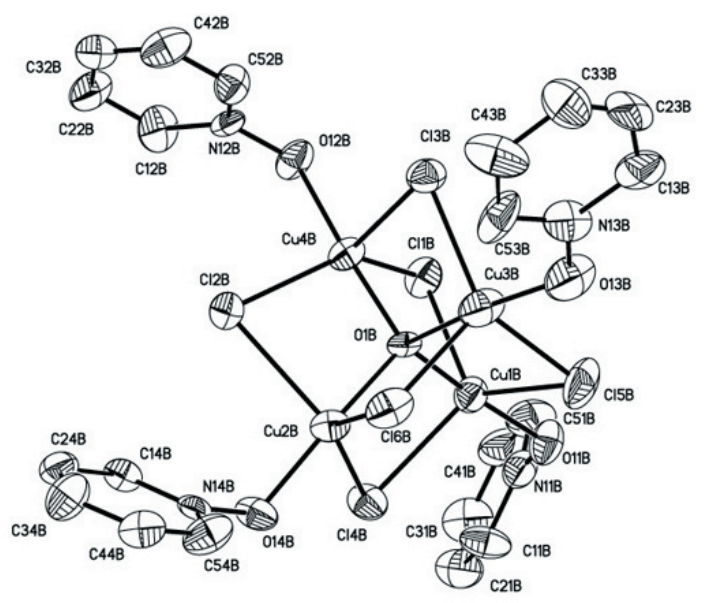

Fig. 2: Molecular Structure of $\left[\left(\mathrm{Cu}_{4} \mathrm{OCl}_{6}\right)(\mathrm{PyNO})_{4}\right] \cdot 1 / 5\left(\mathrm{H}_{2} \mathrm{O}\right)(2)$.

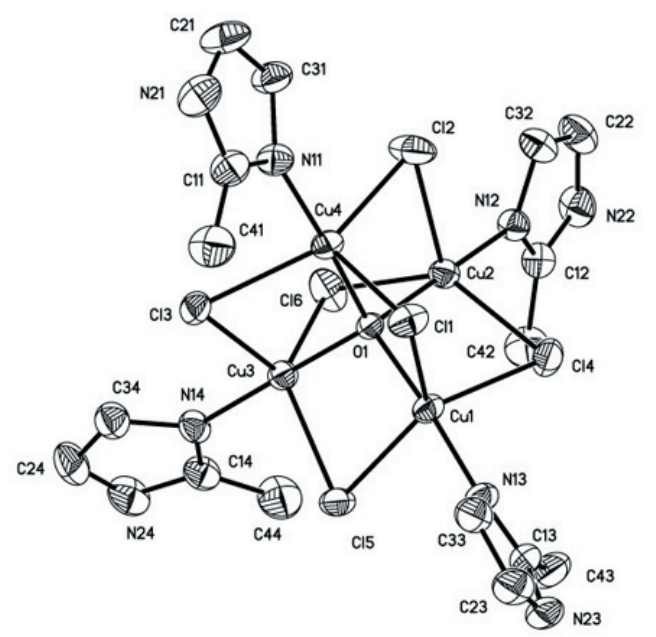

Fig. 3: Molecular Structure of $\left[\left(\mathrm{Cu}_{4} \mathrm{OCl}_{6}\right)(\mathrm{MeIm})_{4}\right] \cdot 3\left(\mathrm{CH}_{3} \mathrm{OH}\right)(3)$.
In all three structures the four copper atoms bound to $\mathrm{O} 1$ define an almost perfect tetrahedron while each chlorine atom coordinates to two different $\mathrm{Cu}_{\mathrm{i}}, \mathrm{Cu}_{\mathrm{j}}$ centers, laying at the bisectors of the corresponding $\mathrm{Cu}_{\mathrm{i}}-\mathrm{O} 1-\mathrm{Cu}_{\mathrm{j}}$ angles. The symmetry of this almost tetrahedral arrangement $\mathrm{C}_{3}$, where the axe 3 is defined by the $\mathrm{Cu} 4$ - $\mathrm{O} 1$ distance and the vertical plane by the $\mathrm{Cu} 4, \mathrm{O} 1$ and $\mathrm{Cu} 1$ atoms in the case of (1). The $\mathrm{Cl}_{6}$ array thus conformed defines a nearly perfect octahedron centered at, though beyond bonding distance to, the central oxygen $\mathrm{O} 1$ and interpenetrating the copper tetrahedron. The slight deviation of each core from a regular geometry is responsible of the different magnetic properties of each compound, as we shall try to demonstrate below. The detailed discussion of the X-ray crystal structures, data collection, structure solution, and refinement of these complexes can be found in reference [12].

The coordination geometry around each metal center is a irregular bipyramid, where the percentage trigonal distortions from the square pyramidal geometry of the atomic arrangement around the four $\mathrm{Cu}$ (II) atoms are $\tau$ ranging between $74-87 \%$ for (1), $62-85 \%$ for (2) and $69-82 \%$ for (3) [13].

The complexes were characterized on the bases of magnetic measurement. Variable temperature $(5-300 \mathrm{~K})$ magnetic susceptibility data were collected for a polycrystalline sample of compounds (1), (2) and (3) in a 0.1T field.

The magnetic properties of the tetrameric complexes under the form of the $\chi_{M} T$ product versus $T$ plots $\left(\chi_{M}\right.$ being molar magnetic susceptibility per tetrameric molecule and $\mathrm{T}$ the absolute temperature) are shown in Fig.
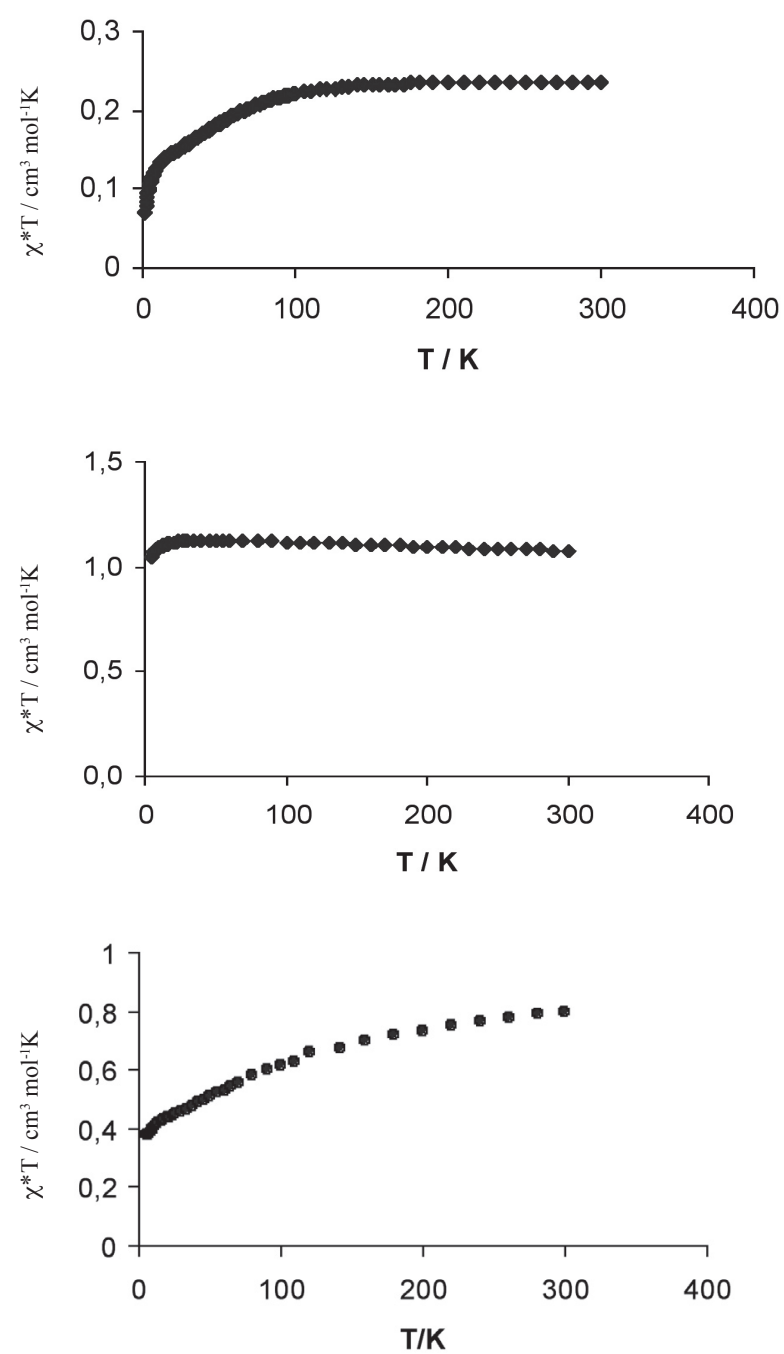

Fig. 4: Temperature dependence of the $\chi \mathrm{MT}$ product for (1), (2) and (3) complexes. 
For the complex $\left[\left(\mathrm{Cu}_{4} \mathrm{OCl}_{6}\right) \mathrm{Cl}(\mathrm{PhIm})_{3}\right] \cdot(\mathrm{HPhIm}) \mathrm{H}_{2} \mathrm{O}(1)$, the data values in the $40-300 \mathrm{~K}$ range are indeed well-fitted by a Curie-Weiss law, $\mathrm{C}=0.25$ and $\theta=-16.94 \mathrm{~K}$.

The $\chi_{\mathrm{M}} \mathrm{T}$ product remains constant during cooling from room temperature to $150 \mathrm{~K}$ and it decreases slowly at lower temperature reaching minimum value of $0.114 \mathrm{~cm}^{3} \mathrm{~mol}^{-1} \mathrm{~K}$.

At $300 \mathrm{~K}, \chi_{\mathrm{M}}^{\mathrm{T}}$ is $0.235 \mathrm{~cm}^{3} \mathrm{~mol}^{-1} \mathrm{~K}$ which corresponds to an effective magnetic moment $\left(\mu_{\text {eff }}\right)$ of $1.37 \mathrm{MB}$. This value is smaller than the expected for four independent copper (II) ions $\left(\mu_{\text {eff }}=3.46 \mathrm{MB}\right)$.

For the complex $\left[\left(\mathrm{Cu}_{4} \mathrm{OCl}_{6}\right)(\mathrm{PyNO})_{4}\right] \cdot 1_{5}\left(\mathrm{H}_{2} \mathrm{O}\right)(2)$ the data obey the Curie -Weiss law and a least-squares calculation of $\mathrm{C}$ and $\theta$ (the Curie Weiss constant ) using measurements in the whole temperature range resulted in $\mathrm{C}=1.084 \mathrm{~cm}^{3} \mathrm{~mol}^{-1}$ and $\theta=1.20 \mathrm{~K}$. The low positive value of $\theta$ is indicative of a weak ferromagnetic interaction between tetrameric compounds. In this case, the $\chi_{\mathrm{M}} \mathrm{T}$ product decreases slowly from 1.078 to $1.066 \mathrm{~cm}^{3} \mathrm{~mol}^{-1} \mathrm{~K}$ between 300 and $6 \mathrm{~K}$.

For the complex $\left[\left(\mathrm{Cu}_{4} \mathrm{OCl}\right)(\mathrm{MeIm})_{4}\right] \cdot 3\left(\mathrm{CH}_{3} \mathrm{OH}\right)$ (3) the magnetic susceptibility data obey the Curie-Weiss law, using measurements in the 45300 temperature range resulted in $\mathrm{C}=0.905 \mathrm{~cm}^{3} \mathrm{~mol}^{-1}$ and $\theta=-44.14 \mathrm{~K}$. The negative value of $\theta$ is indicative of an antiferromagnetic interaction between complexes.

The $\chi_{\mathrm{M}}$ T product at $300 \mathrm{~K}$ is equal to $0.800 \mathrm{~cm}^{3} \mathrm{~mol}^{-1} \mathrm{~K}$, this value is lower than the theoretical value for four uncoupled copper (II) ions, and gradually decreases to $0.376 \mathrm{~cm}^{3} \mathrm{~mol}^{-1} \mathrm{~K}$ at $6 \mathrm{~K}$.

The tetrameric copper complexes have been classified in three classes in relation to the existence of a maximum in the temperature dependence of the effective magnetic moment $[14,15]$. In class I, the magnetic moments decrease monotonically with decreasing temperature, and in class II and class III, the magnetic moment passes through a maximum and then decreases at lower temperatures. (Class II complexes have a strong maximum, while class III complexes have a slight maximum in the $\mu$ vs T curve).

In the complexes described in this paper the distortion from the idealized tetrahedral geometry permits us to describe the cluster in the $\mathrm{C}_{3 \mathrm{v}}$ symmetry group.

The $\mathrm{Cu}-\mathrm{Cu}$ distances can be classified in two groups: a group of short distances, and a second group of the large distance.

For the complex (1) the short distances are $\mathrm{Cu}(1)-\mathrm{Cu}(2)=3.066 \AA, \mathrm{Cu}(1)-$ $\mathrm{Cu}(3)=3.094 \AA, \mathrm{Cu}(2)-\mathrm{Cu}(4)=3.118 \AA$, and large distances are $\mathrm{Cu}(1)-\mathrm{Cu}(4)=$ $3.127 \AA, \mathrm{Cu}(2)-\mathrm{Cu}(3)=3.156 \AA$, and $\mathrm{Cu}(3)-\mathrm{Cu}(4)=3.140 \AA$.

For the complex (3) the short distances are $\mathrm{Cu}(1)-\mathrm{Cu}(2)=3.114 \AA, \mathrm{Cu}(2)$ $\mathrm{Cu}(4)=3.094 \AA, \mathrm{Cu}(1)-\mathrm{Cu}(3)=3.115 \AA$, and large distances are $\mathrm{Cu}(1)-\mathrm{Cu}(3)=$ $3.138 \AA, \mathrm{Cu}(3)-\mathrm{Cu}(4)=3.143 \AA$, and $\mathrm{Cu}(1)-\mathrm{Cu}(4)=3.135 \AA$.

The magnetic susceptibility under $\mathrm{C}_{3 \mathrm{v}}$ symmetry is given by the expression derived from the Heisenberg spin operator, $\hat{H}=-\sum_{i j} J_{i j} S_{i} S_{j}$ the

exchange integral $\mathrm{J}$ is negative for antiferromagnetic interaction and positive for ferromagnetic interaction [16].

$$
\chi_{\mathrm{m}}=\frac{N \beta^{2} g^{2}}{k T} \frac{\left\{10+4 \exp \left[-\left(3 J_{1}+J_{2}\right) / 2 k T\right]+2 \exp \left[-2 J_{2} / k T\right]\right\}}{\left\{5+6 \exp \left[-\left(3 J_{1}+J_{2}\right) / 2 k T\right]+3 \exp \left[-2 J_{2} / k T\right]+2 \exp \left[-3\left(J_{1}+J_{2}\right) / 2 k T\right]\right\}}
$$

In this equation $\mathrm{J}_{1}$ and $\mathrm{J}_{2}$ correspond to exchange constants associated to short and long distances respectively. The $\mathrm{C}_{3 \mathrm{v}}$ coupling is shown in scheme 1
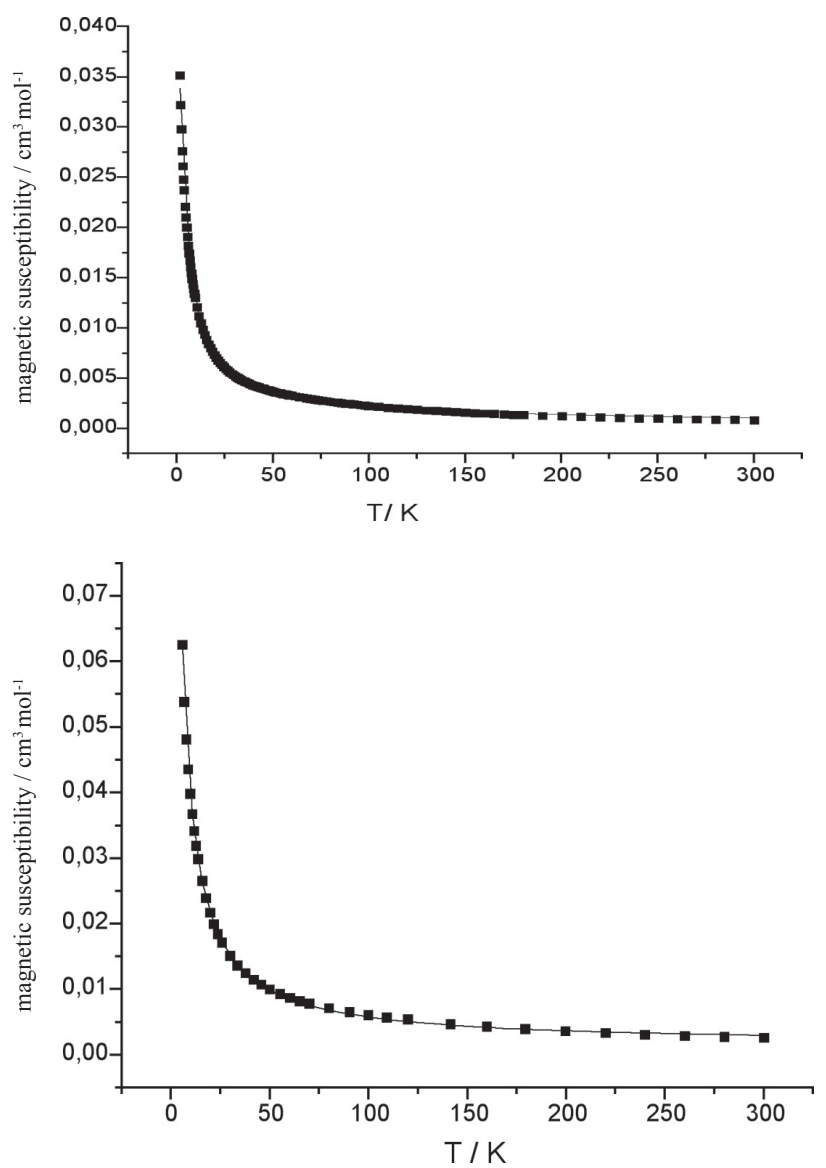

Fig. 5: Temperature dependence of the magnetic susceptibility for (1) and (3). The solid lines correspond to the best fit with the model described in the text.

The result of this fit, which is displayed as the solid lines in figure 5 yields values of $J_{1}=0.15 \mathrm{~cm}^{-1} \mathrm{~J}_{2}=-1.71 \mathrm{~cm}^{-1}$ for $(1)$ and $\mathrm{J}_{1}=-0.52 \mathrm{~cm}^{-1}$ and $\mathrm{J}_{2}=-5.3 \mathrm{~cm}^{-1}$ for (3) with an agreement factor of $\mathrm{R}=3.08 \times 10^{-4}$ for (1) and $\mathrm{R}=1.10 \times 10^{-4}$ for (3) $\left(\mathrm{R}=\sum\left[\left(\chi_{\mathrm{m}}\right)_{\mathrm{obs}}-\left(\chi_{\mathrm{m}}\right)_{\text {calc }}\right]^{2} / \sum\left[\left(\chi_{\mathrm{m}}\right)_{\mathrm{obs}}\right]^{2}\right)$.

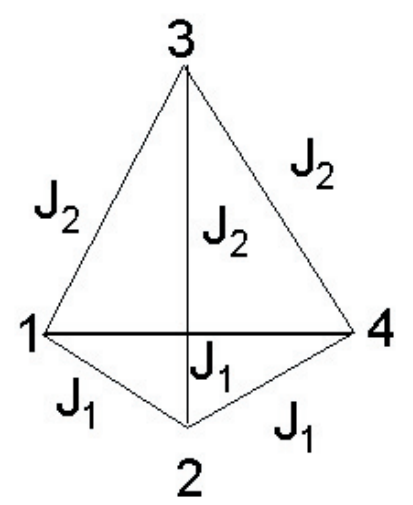

Scheme1 
TABLE 1. Antibacterial activity of copper complexes

\begin{tabular}{|c|c|c|c|}
\hline \multirow{2}{*}{ Bacteria } & \multicolumn{3}{|c|}{$\operatorname{MIC}(\mu \mathrm{g} / \mathrm{mL})^{*}$} \\
\hline & $\begin{array}{c}{\left[\mathrm{Cu}_{4} \mathrm{OCl}_{7}(\mathrm{PhIm})_{3}\right](\mathrm{HPhIm})_{3} \mathrm{H}_{2} \mathrm{O}} \\
(1)\end{array}$ & $\underset{(2)}{\left[\mathrm{Cu}_{4} \mathrm{OCl}_{6}(\mathrm{Py}-\mathrm{NO})_{4}\right]^{1} /{ }_{5}\left(\mathrm{H}_{2} \mathrm{O}\right)}$ & {$\left[\mathrm{Cu}_{4} \mathrm{OCl}_{6}(\mathrm{MeIm})_{4}\right] 3 \mathrm{CH}_{3} \mathrm{OH}$} \\
\hline Staphylococcus aureus AB68 & 80 & $>1000$ & $>1000$ \\
\hline Streprococcus sp. SJD1025 & 125 & $>1000$ & $>1000$ \\
\hline Bacillus sp. UDP1 & 75 & $>1000$ & $>1000$ \\
\hline Bacillus cereus GCA250 & 31.3 & $>1000$ & $>1000$ \\
\hline Acinetobacter baumannii PL9060 & 70 & 250 & 125 \\
\hline Escherichia coli BL21 & 62.5 & 75 & 75 \\
\hline Escherichia coli $\mathrm{MC} 4100$ & 62.5 & 75 & 70 \\
\hline Klebsiella pneumoniae RYC492 & 70 & 62.5 & 62.5 \\
\hline Citrobacter sp. & 125 & 125 & 250 \\
\hline $\begin{array}{l}\text { Salmonella enterica } \\
\text { Tiphymurium LT2 }\end{array}$ & 250 & 125 & 125 \\
\hline Shigella flexnerii & 250 & 500 & 500 \\
\hline
\end{tabular}

$*$ Number of assays $=3$

The Table 1 shows the antimicrobial activities of tetranuclear copper complexes synthesized in this work.

The complex (1) shows antibacterial activity against all bacteria tested, $\beta$. cereus is the most sensitive strain against this complex within Gram positive bacteria studied. The complexes (2) and (3) presented activity against Gram negative bacteria only. From Gram negative bacteria tested, E. coli and $K$. pneumoniae presented a greater sensitivity to three copper complexes and S. flexnerii presented a smaller sensitivity.

Under the same conditions the free ligands (4-phenilimidazole, 2methylimidazole and pyridine-N-oxide) and DMSO were inactive.

Although no satisfactory results were obtained for the compound (2), we believe that the model used here provide the appropriate description of the magnetic properties of the copper (II) complexes. This model retains the know structural features and also accurate reproduce the data

In conclusion, we can indicate that the polynuclear copper complexes studied here have weak $\mathrm{Cu}-\mathrm{Cu}$ magnetic interactions, as seen by the calculated $2 \mathrm{~J}$ values, and the lack maximum in the curve $\chi \mathrm{T}$ vs T.

The complexes showed antibacterial activity mainly over Gram negative bacteria, with exception of the complex (1) that showed activity against both Gram positive and Gram negative bacteria. The difference in the antibacterial activity of copper complexes studied in this work probably is associated to ligand type and its space distribution around the complex core, since the core of the three complexes has a similar structure.

\section{ACKNOWLEDGEMENTS}

This research was supported in part by FONDECYT (Project 1020122). We are also greateful to Region de Bretagne. P.C acknowledges to MECESUP $\mathrm{UCH}-0116$ for doctoral scholarship.

\section{REFERENCES}

[1] J.R.J. Sorenson, Chem. Br. 16 (1984) 1110.

[2] R.K. Gouch, T.W. Kensler, L.W. Oberley, R.J. Sorenson, K.D. Karlin, J. Zubieta (Eds.), Biochemical and Inorganic Copper Chemistry, Vol. 1, Adenine, New York, (1986), p. 139.

[3] J.R.J. Sorenson, Prog. Med. Chem. 26 (1989) 437.

[4] R.N. Patel, Nripendra Singh, K.K. Shukla, U.K. Chauhan, S. Chakraborty, J. Niclos-Gutierrez, A. Castineiras. J. Inorg. Biochem. 98 (2004) 231.

[5] N. Jiménez-Garrido a, L. Perelló, R. Ortiz, G. Alzuet, M. GonzálezÁlvarez, E. Cantón, M. Liu-González, S. García-Granda, M. PérezPriede. J. Inorg. Biochem. 99 (2005) 677.

[6] A.M. Atria, R. Baggio, M.T. Garland, O. Gonzalez, J. Manzur, O. Peña, E. Spodine. J. of Crystallographic and Spectroscopy Research 23, 12 (1993) 943

[7] M. Murugesu, R. Clérac, B. Pilawa, A. Mandel, C. E. Anson, A.K. Powell. Inorg. Chim. Acta 337 (2002) 328.

[8] C.N. Kato, M. Hasegawa, T. Sato, A. Yoshizawa, T. Inoue, W. Mori. J. Catal. 230 (2005) 226.

[9] A.M. Atria, A. Vega, M. Contreras, J. Valenzuela, E. Spodine. Inorg. Chem. 38 (1999) 5681.

[10] K.L. Kwaniewska. Bull. Environ. Contam.Toxicol. 27 (1981) 289.

[11] National Committee for Clinical Laboratory Standards. Methods for Dilution Antimicrobial Susceptibility Tests for Bacteria That Grow Aerobically-Fifth Edition: Approved Standard M7-A5. NCCLS, Wayne, PA, USA. (2000).

[12] P.Cortés, A. M. Atria, M.T. Garland, R. Baggio. C62 Submitted to Acta Cryst (2006).

[13] A.W. Addison, T.N. Rao, J.Reedojk, J. van Rijn, G.C. Verschoor. J. Chem. Soc. Dalton Trans. (1984) 1349.

[14] R.F. Drake, V.H. Crawford, W. Hatfield. J.Chem.Phys. 60 (1974) 4525.

[15] H.Wong, H.Dieck, C.O'Connors, E. Sinn. J. Chem. Soc. Dalton Trans. (1980) 786

[16] P. Weinberger, R. Schamschule, K. Mereiter,L. Dlhán, R. Boca, W. Linert. J. M. Struct. 446 (1998) 115. 